\title{
APPLYING HEALTH EDUCATION PACKAGE ABOUT SEXUAL AND REPRODUCTIVE HEALTH FOR UNIVERSITY MALE STUDENTS ${ }^{1}$ Mohamed Mustafa Abd Algany, ${ }^{2}$ Sahar Mohammed Soliman, ${ }^{3}$ Samar El Hosieny Abdel-Raoof
}

Assist. Lecturer in Community Health Nursing, ${ }^{2,3}$ Assist.Prof. in Community Health Nursing, Mansoura University

\begin{abstract}
Background: Human reproduction involves a man and a woman. Since men participate in sexual decisions and behavior associated with reproduction then reproductive health is a concern for all men of all ages. Therefore the earliest part of the life course adolescence and early adulthood is important because it is the most fascinating and complex transitions (physical, psychological and behavioral) in the life span. Promoting the sexual and reproductive health of young men is a keystone to enhance their health overall, to reduce some of the major health risks they face, and to establish habits that will protect them throughout their lives. Proper information about this subject can help them to handle these changes without any stress. For that the aim of this paper is to assess the application of health education package about sexual and reproductive health for University male students'. Method: A quasi-experimental (one group, pre post-test) research was used. The minimum sample size comprised 381 students. Proportion allocation technique was used to select the required students' number of first, second and third year at studied faculties. A total number of students sample was 386 students. Three tools were used for data collection: Structured self-administered questionnaire to assess male students' sociodemographic and economic characteristics, structured self-administered questionnaire to assess male students' knowledge and self-administered scale to assess male students' attitude. Results: There was highly statistical significant difference in knowledge level before and after application of educational package about sexual and reproductive health $(\mathrm{t}=151.995, \mathrm{P} \leq 0.01)$. Concerning attitude of students toward sexual and reproductive health, there was significant differences before and after application of educational package $(\mathrm{p}<0.001)$. Conclusion: The study concluded that almost all university male students had poor knowledge score level about sexual and reproductive health before application of education package and all of them had good knowledge score level after application Recommendations: Academic learning should be occupied with sexual and reproductive health. Provide proper information for adolescent boys about sexual and reproductive health and guidance about their sexual responsibilities and relationships. Develop global service education package about sexual and reproductive health for adolescent boys and men to support providers of this subject meet the specific and diverse needs of them. Conducting Public health campaigns about the impact of denial sexual and reproductive health on adolescents.
\end{abstract}

Key Words: Educational Package - Knowledge - Male Students - Sexual and Reproductive Health

\section{Introduction:}

Adolescent period is the second decade of life. It is a crucial and dynamic time in the lives of all young people, when puberty is experienced ${ }^{(\mathbf{1})}$. Adolescence is a life phase in which the opportunities for health are great and future patterns of adult health are established. Health in adolescence is the result of interactions between prenatal and early childhood development; biological and social role accompany puberty are changing, shaped by social determinants, risk factors and 
protective factors that affect the uptake of health-related behaviours ${ }^{(2)}$.

Like many developing countries Egypt has a relatively young population, approximately one fourth of the total population of 94,798,827 living in Egypt recorded in the 2017 Census consists of young people (10-24 year old) ${ }^{(3)}$. This means every year a large number of young people become sexually active for the first time. Egypt has accelerated its commitment to the International Conference on Population and Development (ICPD) Program of Action (1994) by hosting this conference which focuses on the sexual and reproductive health of adolescents.

Recently, the approach to youth health and development has taken a turn from the traditional view of youth as victims and passive recipients to one that contribute in the community as competent citizens ${ }^{(4)}$.

A focus on adolescence is central to the success of many public health agendas, including the Millennium Development Goals aiming to reduce HIV/AIDS, and emphases on sexual health and sexual transmitted diseases. Greater attention of adolescence is needed within each of these public health domains if global health targets are to be met ${ }^{(5)}$. Strategies that place the adolescent years centre stagerather than focusing only on specific health agendas-provide important opportunities to improve health, both in adolescence and later in life.

International Conference on Population and Development [ICPD] (6) recommended that special efforts should be made to promote the active involvement of men in the prevention of sexually transmitted diseases (STDs), including human immunodeficiency virus (HIV) infection. This recommendation can be applicable if the sex education became an integral part of the learning process beginning in childhood including those with physical learning or emotional difficulties and continuing into adult life. In addition, development of communication and decision-making skills, encourage exploration of values and moral values, considering sexual and reproductive health can foster self-esteem, self-awareness and raises a sense of moral responsibility to avoid and resist sexual experience $^{(7)}$.

Therefore community health male nurses have an important roles in promoting sexual and reproductive for adolescents through encouragement of male adolescents access to accurate, safe, effective, affordable, and acceptable sexual and reproductive health services. Also, they can directly provide youthfriendly care as well as advocate for youthfriendly practices within their health system $^{(8)}$.

Community health male nurses should encourage male adolescents to involve necessary in programs related to sexual and reproductive health to improve their partners' sexual and reproductive health, and is likely to be more effective than a program that only targets women ${ }^{(9)}$. Aim of the study:

To assess the application of health education package about sexual and reproductive health for University male students'.

\section{Subjects and Method}

Design:

A quasi experimental design was used in this study.

\section{Setting:}

The study was carried out in the different faculties affiliated to Mansoura University as the following:

Health sciences faculties were including: Faculty of Medicine, Dentistry, Pharmacy, Veterinary and Nursing. 


Non health sciences faculties were
including:

Faculty of Science, Engineering, Agriculture, Computing and information technology, Arts, Commerce, Education, Law, Specific Education, Tourism and Hotels, and Physical education.

\section{Sample:}

The required sample size included in this study was 381 of male students, when $\alpha=5 \%$, Population size $=43855$ male students registered at Mansoura University at the first, second and third years, desired precision $=4 \%$, expected prevalence of correct knowledge about sexual health among adolescent males $=50 \%$ and design effect $=1^{\text {(10) }}$.

This subject was chosen conveniently according to the following criteria:

1. Adolescent stage (from 18 to more than 22 years)

2. Were not married

\section{Tools for data collection:}

\section{Structured self-administered questionnaire to assess male students' socio-demographic and economic characteristics: included two parts:}

Part I: The first part to assess male students' socio-demographic characteristics such as: age, residence, faculty, and academic year.

Part II: The second part to assess male students' social level by using El-Gelany et al., (2012) ${ }^{[11]}$ scale.

\section{Structured self-administered questionnaire to assess male students' knowledge}

The questionnaire was developed to assess male students' knowledge about sexuality, sexual and reproductive health including: sexual developmental stages, wet dream, masturbation, homosexuality and sexual transmitted diseases.
The tool was classified into 6 categories; all of these categories were composed of 70 questions. One mark was awarded for each correct answer as the following:

1. Definition and anatomy of reproductive system and maturation changes (It includes 52 items $=52$ marks).

2. Reproduction, definition of sex, and sexual needs (It includes 15 items $=$ 15 marks).

3. Masturbation and sexual stimulants (It includes 16 items $=16$ marks .

4. Abnormal sexual behavior and homosexuality (It includes 13 items $=$ 13 marks).

5. STDs, AIDS, Gonorrhea, Syphilis, and Hepatitis B (It includes 39 items $=39$ marks).

6. Reproductive health and family planning (includes 8 items $=8$ marks).

The total scores of the knowledge ranged from 0 to 143 . The knowledge level was consisting of three categories as:

- Poor $=$ scores less than $50 \%$ of total scores $(0-$ less than 71.5).

- Fair $=$ scores $50 \%$ to less than $75 \%$ of total scores (71.5 - less than 107.25).

- $\operatorname{Good}=$ scores $75 \%$ of total scores $(107.25-143)$.

3.Self-administered scale to assess male students' attitude

This scale was developed by the researcher to assess male students' attitudes and culture impact toward sexuality, sexual and reproductive health, and sexual health education, which composed of 48 statements requiring a response on 4 point Likert-rating scale with 4 continuum (agree, strongly agree, disagree, strongly disagree). A scoring system was used to quantify the male students' attitude four marks were given to strongly agree, three marks to agree, two to disagree and one mark to strongly disagree. If the statements were negative, 
the scoring system was reversed in SPSS as one mark was given to strongly agree, two marks were given to agree, three marks to disagree, and four marks to strongly disagree which made up a total score of 192 marks as the following:-

1 - Sex (included 11 items $=44$ marks).

2-Abnormal sexual behavior and sexual diseases (included 15 items $=60$ marks).

3-Reproductive health (included 6 items $=24$ marks).

4-Sexual health education (included 16 items $=64$ marks)

\section{Method:}

\section{Preparation phase:}

\section{Administrative process}

- An approval was obtained from Research Ethical Committee, Faculty of Nursing, Mansoura University to accomplish this study.

- An official letters from the Faculty of Nursing was submitted to the deans of Faculties of Mansoura University to obtain approval for conducting the study.

- An official permission was obtained from the deans of Faculties of Mansoura University after clarifying the purpose of the study; set the starting point of the study and it is process to gain their cooperation and support during data collection.

\section{Literature review}

Review of national and international literatures on the various aspects of the sexual and reproductive health using scientific published articles, internet search and textbooks. This review was a guide for developing the study tools.

3. Developing of the study tools

- Tools of data collection (I, II, III) were developed by the researcher based on reviewing the relevant literature except part two of the first tool was adopted from El-Gelany et al., (2012) ${ }^{[11]}$.
- A jury panel that involved six experts in the field of community health nursing and statistics tested the content validity of the developed tools, and the required modification were carried out.

- Face validity of the developed tools was tested by using pilot study on $10 \%(n=38)$ of the male students who were selected conveniently from the mentioned settings and were not included in this study. Pilot study was used to evaluate the clarity, applicability and reliability of the research tools, estimate the approximate time required for data collection, identify the possible obstacles or problems that may hinder data collection and overcome measures.

- The reliability was assured by means of Cronbach's coefficient alpha. It indicated that the study tools had a reliability of 0.85 .

- On the basis of collected information; the necessary modification were done, some questions were added and others were clarified or omitted.

Operational phase:

This phase started from the beginning of February 2017 and ended at May 2018.

This phase was consisted of the following steps:

1.The first step (Initial data collection):

- The researcher was provided simple explanation to the students about the aim of the study in the beginning. Initial assessment was done through two days/week. The number of visits was varied from faculty to another according to the required number of studied students in each faculty (8.5 am to $2.5 \mathrm{pm}$ ).

- Self-administrated questionnaires distributed to male students $(n=386)$ for initial data collection to obtain 


\begin{tabular}{|c|c|}
\hline $\begin{array}{l}\text { data about male students' socio- } \\
\text { demographic and economic } \\
\text { characteristics, knowledge and } \\
\text { attitude. } \\
\text { 2. The second step (Development of } \\
\text { health education package): } \\
\text { - Health education package was } \\
\text { developed based on the initial } \\
\text { assessment results which revealed } \\
\text { that most of the students had poor } \\
\text { knowledge about sexual and } \\
\text { reproductive health. Accordingly, } \\
\text { stated objectives, required contents } \\
\text { were included, teaching strategy, } \\
\text { media, and required time for } \\
\text { conducting the health education } \\
\text { package was estimated and the } \\
\text { duration of each part was included. } \\
\text { 3he third step (Applying of health } \\
\text { education package session): } \\
\text { - Male students were divided to } 19 \\
\text { groups, each group ranged from } 15 \\
\text { to } 20 \text { students. Each group received } \\
\text { two health education sessions per } \\
\text { week. The duration of session } \\
\text { ranged from } 45-60 \text { minutes. } \\
\text { - According to permitted facilitations } \\
\text { of the faculties, some sessions were } \\
\text { conducted at computer skill labs } \\
\text { of previous session and objectives } \\
\text { of the new session ,using a very } \\
\text { simple slang language without } \\
\text { and other sessions were conducted } \\
\text { in class room by using researcher } \\
\text { laptop. } \\
\text { - Introductory sessions wiew and avoid sarcasm or } \\
\text { conducted in the preliminary } \\
\text { meeting with male students to } \\
\text { explain the aim of health education } \\
\text { package. Also orient the male } \\
\text { students about the phase of package } \\
\text { application schedule, duration, } \\
\text { place and their rules and } \\
\text { emphasizing the importance of } \\
\text { continuous attendance, active } \\
\text { participation, respect others point of } \\
\text { intens. }\end{array}$ & $\begin{array}{l}\text { ignoring motivation } \\
\text { reinforcement techniques. } \\
\text { - Different teaching methods were } \\
\text { used during the sessions namely; } \\
\text { interactive lecture, brainstorming, } \\
\text { and interactive discussion. Also } \\
\text { different media was utilized as } \\
\text { audiovisual material, black board, } \\
\text { power point presentation and } \\
\text { printed hand out to be used as } \\
\text { memorial reference. } \\
\text { 4. The fourth step (Evaluation): } \\
\text { Evaluation was done immediately } \\
\text { after applying the health education } \\
\text { package sessions by using second and } \\
\text { third tool. } \\
\text { Ethical considerations } \\
\text { - An approval was obtained from the } \\
\text { Faculty of Nursing Research Ethics } \\
\text { Committee. } \\
\text { - Students' oral approval was obtained } \\
\text { before the beginning of the study. } \\
\text { Each student had the right to } \\
\text { withdraw from the study at any time. } \\
\text { - They assured that collected data would } \\
\text { be treated confidentially and would be } \\
\text { used only for research purpose. } \\
\text { - Pearson correlation coefficients were } \\
\text { used to estimate correlation between } \\
\text { the study variable to clarify positive } \\
\text { or negative correlation. } \\
\text { - Data was sorted, coded, organized, } \\
\text { categorized and then transferred into } \\
\text { especially designed formats. } \\
\text { - Data was analyzed using SPSS (stand } \\
\text { for statistical product and service } \\
\text { solutions) version } 24 \text {. } \\
\text { results when P-value <0.05 it is a } \\
\text { Paired sample t test was used to } \\
\text { estimate difference between pre and } \\
\text { post application. } \\
\text { P-value to determine significance of } \\
\text { stignificant difference. } \\
\text { - test) was used for } \\
\text { - }\end{array}$ \\
\hline
\end{tabular}




\section{Results:}

Table (1) shows distribution of studied male students according to their socio-demographic and economic characteristics. The mean age of male students was 20.07 (1.47) years. About half of them $(54.7 \%)$ live in rural areas, and all of them $(100 \%)$ were single. In relation to socio-economic level nearly half of them $(53.9 \%)$ belonged to middle socio-economic class.

Table (2) illustrates distribution of male students according to their scores level of knowledge regarding reproductive system pre and post health education package application. It was observed that $(81.6 \%)$ of male students had poor knowledge score level with a mean of 4.179 (2.541) marks related to male reproductive system pre education package application. However, $94.3 \%$ of them had good knowledge score level post health education package application with a mean $11.477 \pm 1.154$ marks. There was highly statistical significant difference between pre and posttest regarding the previous item $(\mathbf{t}=\mathbf{5 1 . 8 9 7}, \mathbf{P} \leq \mathbf{0 . 0 1})$. In relation to female reproductive system, $87 \%$ of students had poor knowledge score level with a mean 0.974 (1.246) of marks pre health education package application. While their knowledge had good score level $91.5 \%$ post education package application with a mean 4.5 (.665) of marks. There was highly statistical significant difference between pre and posttest regarding female reproductive system $(\mathbf{t}=47.344, \mathbf{P} \leq \mathbf{0 . 0 1})$.

Table (3) clarifies distribution of male students according to their scores level of knowledge regarding female maturation pre and post health education package application. It was observed that $94.3 \%$ of male students had poor knowledge score level with a mean 4.298 (2.593) of marks related to female maturation pre education package application. While almost all of them 99.7 $\%$ had good knowledge score level with a mean 17.544 (1.099) marks post application of health education package. There was highly statistical significant difference between pre and posttest regarding the previous item $(\mathbf{t}=\mathbf{9 3 . 2 3 5}, \mathbf{P} \leq$ 0.01).

Table (4) explains distribution of male students according to their scores level of knowledge regarding male maturation pre and post health education package application. It was detected that $93.8 \%$ of male students had poor knowledge score level with a mean 5.292 (2.131) of marks related to male maturation pre education package application. While $98.7 \%$ of them had good knowledge score level with a mean 14.611 (1.258) of marks post education package application. There was highly statistical significant difference between pre and posttest concerning the previous item $(\mathbf{t}=\mathbf{7 4 . 9 0 9}, \mathrm{P} \leq \mathbf{0 . 0 1})$.

Table (5) explains distribution of male students according to their scores level of knowledge about reproduction and sex pre and post education package application. It was detected that $90.2 \%$ of male students had poor knowledge score level with a mean 1.124 (1.022) of marks related to reproduction pre education package application. Although $90.2 \%$ of them had good knowledge score level with a mean 4.438 (.744) of marks post education package application. There was highly statistical significant difference between pre and posttest concerning reproduction $(\mathbf{t}=\mathbf{4 8 . 1 7 3}, \quad \mathbf{P} \leq \mathbf{0 . 0 1})$. In relation to sex, $97.2 \%$ of male students had poor knowledge score level with a mean 2.725 (1.451) of marks related to sex pre education package application. While their knowledge had good score level 86 $\%$ post education package application with 
a mean 8.725 (1.077) of marks. There was highly statistical significant difference between pre and posttest toward sex $(\mathrm{t}=$ 66.882, $\mathrm{P} \leq \mathbf{0 . 0 1})$.

Table (6) portrays distribution of students according to their scores level of knowledge about masturbation and sexual stimulants pre and post health education package application. It was noticed that $93.5 \%$ of male students had poor knowledge score level with a mean 1.124 (.886) of marks related to masturbation pre education package application. Whereas $79 \%$ of them had good knowledge score level with a mean 3.767 (.475) of marks post education package application. There was highly statistical significant difference between pre and posttest concerning masturbation $(\mathbf{t}=\mathbf{4 5 . 8 8 5}, \quad \mathbf{P} \leq \mathbf{0 . 0 1})$. In relation to sexual stimulants, $96.6 \%$ of male students had poor knowledge score level with a mean 1.547 (1.958) of marks related to sex pre education package application. While their knowledge had good score level $91.5 \%$ post education package application with a mean 10.940 (1.003) of marks. There was highly statistical significant difference between pre and posttest toward sexual stimulants $(\mathrm{t}=\mathbf{8 1 . 5 0 3}, \mathrm{P} \leq \mathbf{0 . 0 1})$.

Table (7) explains distribution of male students according to their scores level of knowledge about abnormal sexual behavior "Homosexuality" pre and post health education package application. It was observed that $93.5 \%$ of male students had poor knowledge score level with a mean 3.590 (1.676) of marks related to homosexuality pre education package application. Although $98.2 \%$ of them had good knowledge score level with a mean 11.720 (1.037) of marks post education package application. There was highly statistical significant difference between pre and posttest regarding homosexuality $(\mathbf{t}=$ 81.039, $\mathrm{P} \leq \mathbf{0 . 0 1})$.
Table (8) describes distribution of male students according to their scores level of knowledge about sexual transmitted diseases pre and post health education package application. It was noticed that $15.5 \%, 4.9 \%$ of male students didn't know the sexual transmitted diseases and the availability of vaccination to these diseases, respectively. However, post education package application 94.8\%, 92\% of male students knew sexual transmitted diseases and the availability of vaccination, respectively. Regarding to acquired human immunodeficiency virus (AIDS), It was observed that $91.5 \%$ of male students had poor knowledge score level with a mean 1.609 (1.790) of marks pre education package application. Even though $99.5 \%$ of them had good knowledge score level with a mean 8.520 (.629) of marks post health education package application. There was highly statistical significant difference between pre and posttest regarding AIDS $(\mathbf{t}=\mathbf{7 2 . 6 5 4}, \quad P \leq \mathbf{0 . 0 1})$. Concerning to Syphilis, It was detected that $94 \%$ of male students had poor knowledge score level with a mean .632 (1.752) of marks pre education package application. While $95.9 \%$ of them had good knowledge score level with a mean 8.187 (.907) of marks post education package application. There was highly statistical significant difference between pre and posttest regarding Syphilis $(\mathbf{t}=\mathbf{7 6 . 1 8 1}, \mathbf{P} \leq \mathbf{0 . 0 1})$. In relation to Gonorrhea, It was recognized that $96.1 \%$ of male students had poor knowledge score level with a mean .394 (1.388) of marks related to Gonorrhea pre education package application. While $96.9 \%$ of them had good knowledge score level with a mean 8.218 (.825) of marks post education package application. There was highly statistical significant difference between pre and posttest regarding Gonorrhea $(\mathbf{t}=\mathbf{9 3 . 9 7 7}, \mathbf{P} \leq \mathbf{0 . 0 1})$. About 
Hepatitis B, It was recognized that $95.6 \%$ of male students had poor knowledge score level with a mean 1.358 (1.585) of marks pre education package application. Although $96.1 \%$ of them had good knowledge score level with a mean 8.316 (.821) of marks post education package application. There was highly statistical significant difference between pre and posttest regarding Hepatitis B $(\mathbf{t}=\mathbf{7 6 . 8 2 1}$, $\mathbf{P} \leq$ 0.01).

Table (9) refers to distribution of students according to their scores level of knowledge about reproductive health pre and post education package application. It was observed that $97.4 \%$ of male students had poor knowledge score level with a mean 1.440 (1.371) of marks related to reproductive health pre education package application. However, $78.8 \%$ of them had good knowledge score level with a mean 7.168 (.874) of marks post education package application. There was highly statistical significant difference between pre and posttest regarding reproductive health (t=65.850, $\mathbf{P} \leq \mathbf{0 . 0 1})$.

Table (10) discuss distribution of male students according to their total scores level of knowledge about sexual and reproductive health pre and post health education package application. It was observed that almost all male students $(99.7 \%)$ had poor knowledge score level with a mean 30.510 (12.434) of marks related to sexual and reproductive health pre health education package application. However, $100 \%$ of them had good knowledge score level with a mean 130.347 (3.591) of marks post health education package application. There was highly statistical significant difference between pre and posttest on the topic of sexual and reproductive health $(\mathbf{t}=\mathbf{1 5 1 . 9 9 5}$, $\mathbf{P} \leq$ 0.01).

Table (11) presents mean difference between attitude categories \& total attitude pre and post health education package application. Regarding to attitude of male students toward sex, abnormal sexual behavior and sexual diseases, reproductive health and sexual education, there was highly statistical significant difference among pre and posttest $(t=44.303, P \leq 0.01),(t=35.397, P \leq 0.01)$, $(\mathbf{t}=$ 25.225, $\mathrm{P} \leq \mathbf{0 . 0 1})$ and $(\mathrm{t}=34.190, \mathrm{P} \leq$

, respectively. Concerning to total attitude of male students toward sexual and reproductive health, there was highly statistical significant difference between pre and posttest $(\mathrm{t}=$ 49.150, $\mathrm{P} \leq \mathbf{0 . 0 1})$.

\section{Discussion:}

The major human resources for the development of any nation are the energy and creativity of a healthy young adult population. Health in general, sexual and reproductive health (SRH) in particular, refer not only to an absence of disease but also to physical, mental, and social wellbeing. When young adults have limited access to sexual and reproductive health information, they have insufficient access for preventive and curative services [12].

Sexual and reproductive health (SRH) are important aspect of normal adolescent growth and development that include biological sex, gender roles identity, sexual orientation, sexual behavior, and reproduction [13]. Young people require access to a wide range of $\mathrm{SRH}$ education and clinical services to promote positive sexual development [14] and to reduce social and economic adverse on health consequences of sexual behaviors [15].

Also Ab Rahman et al., (2011) [17] reported that it's important to strength sexual and reproductive health education to adolescents; thus, preparation of this subject can reduce the prevalence of sexual transmitted diseases and improve sexual life for young adult [18]. 
Collectively, these issues have forced us as a community health nurse to develop an health education package about sexual and reproductive health for university male students. To accomplish the development of this package and its implementation throughout the present study, it was mandatory to explore university male students' knowledge in relation to sexual and reproductive health. Regarding to students socio demographic and economic characteristics of the current study, the mean age of male students was 20.07 (1.47) years, more than half of them living in rural area and belonged to middle social class. These findings are matched with several studies.

Firstly, study of Basaran and Naim, (2017) [19], conducted on university students registered in undergraduate programs in Rize, which stated that average age of students was 20.64 (3.432) and $52.8 \%$ lived in the counties and villages. Secondly, study of Meena, Verma, Kishore and Ingle, (2015) ${ }^{[20]}$, conducted on young unmarried men (1825 years) in Delhi, which stated that the median age of participants was 23 years and half of them were residing in rural areas of Delhi. Finally, study of Iqbal, Zakar, Zakar and Fischer, (2017) ${ }^{[18]}$,conducted on adolescents (15-19 years) in Pakistan, which cleared that mean age of adolescents was 17 years and nearly two third of the respondents had middle wealth status.

The rate of growth and development is the most distinctive feature of early puberty [21]. In terms of physical and sexual development, puberty is the developmental period where differences between the sexes become most obvious ${ }^{[22]}$. The present study revealed that the majority of studied male students had poor knowledge score level related to male and female reproductive system before applying health education package. This finding was consistent with Kotwal, Gupta and Gupta, (2008) ${ }^{[23]}$ study findings that conducted in rural schools in Jammu City on the opposite sex, but their knowledge related to male and female reproduction was poor.

In the current study most of male students had poor knowledge score level related to male and female maturation and puberty changes before applying health education package. This finding was agreed with Harshana and Kapoor, $\mathbf{( 2 0 1 8}^{[24]}$, who found poor knowledge score among adolescent boys aged from 15-19 years about development of secondary sexual character and its sequence. Also Dorle et al., (2010) ${ }^{[25]}$, revealed that the majority of secondary school children in Karnataka had poor knowledge score regarding secondary sex characters of both sex.

The current study showed that, the majority of students had poor knowledge related to reproduction process and related to sex and sex practicing before applying health education package. This finding go in the same way with DAS and RAY, (2007) ${ }^{[26]}$, results who illustrated that majority of adolescent boys attended high school and residing in peri-urban and rural areas in India had poor knowledge score related to reproduction.

Moreover, study of Ab Rahman et al., (2011) [17], conducted on secondary school students in Malaysia and study of Tamang, Raynes-Greenow, McGeechan and Black, (2017) ${ }^{[27]}$, conducted amongst young Nepalese men living in Kathmandu valley, they stated that adolescent men had poor knowledge about sex and sexual practice.

At preliminary assessment, the majority of university male students in the present study were not heard about STDs. Only few numbers of them knew 
definition of AIDS, syphilis, gonorrhea and hepatitis B. The same findings were found in the following studies, the first study conducted on German adolescents by Samkange-Zeeb, Mikolajczyk and Zeeb, (2013) ${ }^{[28]}$, revealed that adolescents had low levels of knowledge and awareness of STDs with the exception of HIV/AIDS. The second study conducted by Folasayo et al., (2017) ${ }^{[29]}$, who stated that the health and non-health sciences Malaysians university students had poor score knowledge level related to syphilis, gonorrhea and hepatitis B. Finally, study conducted by Harshana and Kapoor, (2018) ${ }^{[24]}$ on Indian adolescents aged 1519 years, reported that majority of them had partial knowledge regarding names, modes of transmission and prevention of STDs. Although there is difference in the culture context among studied students in the current study and others studies, but there are matching in student's knowledge; most of them had poor knowledge.

While the following studies conducted on young adult aged 15-24 years in Malaysia by Wong, Chin, Low and Jaafar, (2008) ${ }^{[30]}$ by Awang, Wong, Jani and Low, (2013) [31] and by Folasayo et al., (2017) ${ }^{[29]}$ revealed that the majority of young adult were aware of HIV/AIDS. Because Ministry of Health in Malaysia [32] continuously conducted programs to raise young adult awareness about HIV/AIDS.

Family planning is considered an essential component of reproductive health, it play a major role in reducing transmission of HIV [31]. The present study showed that most of male student had poor knowledge score regarding family planning. This findings were in the same line with Abdul-Zahra, Habib and AlMulla, (2016) ${ }^{[33]}$, who stated that most of Basrah University students in Iraq were unfamiliar with family planning and their knowledge level was generally low.

The current study showed that the total knowledge score of male students about sexual and reproductive health before applying health education package was poor, but after applying health education package were improved. There was highly statistical significant difference. This findings were similar to Madeni, Horiuchi and Iida, (2011) ${ }^{[34]}$, findings who found that knowledge score of students aged (11-16) in Tanzania, about reproductive health was poor at preliminary assessment, which improved after applying a reproductive health awareness program. Also, there was highly statistical significant difference.

There was highly statistical significant difference between knowledge level before and after application of health education package about sexual and reproductive health. This result may reflect the effect of health education package on improving students' knowledge. This findings are compatible with studies conducted in Indonesia, by Nugraheni et al., (2018) $)^{[35]}$ and in India, by Manjula, Kashinakunti, Geethalakshmi and Sangam, (2012) ${ }^{[36]}$. They revealed that there was a significant difference between respondent knowledge before and after intervention. There was significant increase in knowledge score after intervention.

Regarding total attitude of students toward sexual and reproductive health, the current study revealed that there is statistically significantly difference before and after application of educational package. In other words, sexual and reproductive health education promotes the attitude of students. These findings are agreed with Mehrabi, Etemadi, Borjali \& Sadipoor, (2016) $)^{(37)}$, findings who conducted their study on girls registered 
in the first year of high school in Iran. They stated that attitude scores about sexual and reproductive health was found to be significantly difference before and after providing educational course in both experimental and control groups.

\section{Conclusion:}

Based on the findings of the present study, it can be concluded that almost all university male students had poor knowledge score level about sexual and reproductive health before application of health education package converted to good knowledge score level after application of health education package, reflecting statistical significant difference. Also there was significant differences in attitude of male students before after application of health education package.

\section{Recommendation:}

1- Academic learning should be occupied with sexual and reproductive health.

2- Provide proper information for adolescent boys about sexual and reproductive health and guidance about their sexual responsibilities and relationships.

3- Develop global service education package about sexual and reproductive health for adolescent boys and men to support providers of this subject meet the specific and diverse needs of them.

4- Conducting Public health campaigns about the impact of denial sexual and reproductive health on adolescents.

5- Future nursing research should focus on sexual and reproductive health. A similar study can be conducted on the same topic with a broader perspective by evaluating a several people in adolescent stage in various setting.

\section{Acknowledgements:}

We would like to thank all students who participated in the study and staff of the community health nursing department at Faculty of Nursing, Mansoura University for their help and cooperation during the study period and appreciate the great efforts of the supervisors in this work.

Table (1) Distribution of the studied students according to their socio-demographic and economic characteristics

\begin{tabular}{|c|c|c|}
\hline 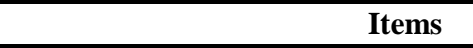 & No (386) & $\%$ \\
\hline $\begin{array}{l}\text { Age (years) } \\
18-<20 \\
20-<22 \\
22-\text { more }\end{array}$ & $\begin{array}{c}123 \\
191 \\
72\end{array}$ & $\begin{array}{l}31.9 \\
49.5 \\
18.7\end{array}$ \\
\hline$\square$ ( SD) & \multicolumn{2}{|c|}{$20.07(1.47)$} \\
\hline $\begin{array}{l}\text { Residence } \\
\text { Rural } \\
\text { Urban } \\
\text { Slums } \\
\end{array}$ & $\begin{array}{c}211 \\
130 \\
45 \\
\end{array}$ & $\begin{array}{l}54.7 \\
33.7 \\
11.7\end{array}$ \\
\hline $\begin{array}{l}\text { Marital status } \\
\text { Single }\end{array}$ & 386 & 100 \\
\hline $\begin{array}{l}\text { Socioeconomic levels } \\
\text { - } \quad \text { Low socio-economic level } \\
\text { - } \quad \text { Middle socio-economic level } \\
\text { - High socio-economic level }\end{array}$ & $\begin{array}{c}105 \\
208 \\
73\end{array}$ & $\begin{array}{l}27.2 \\
53.9 \\
18.9\end{array}$ \\
\hline
\end{tabular}

$\square$ ( SD): Mean (standard deviation) 
Mohamed Mustafa et. al.

Table (44): Distribution of the studied students according to their correct knowledge about reproductive system pre and post health education package application

\begin{tabular}{|c|c|c|c|c|}
\hline \multirow{2}{*}{ Items } & \multicolumn{2}{|c|}{ Pre test } & \multicolumn{2}{|c|}{ Post test } \\
\hline & $\mathrm{N}=386$ & $\%$ & $\mathrm{~N}=386$ & $\%$ \\
\hline Definition of reproductive system & 111 & 28.8 & 352 & 91.2 \\
\hline Male reproductive system organs & 156 & 40.4 & 350 & 90.7 \\
\hline Function of prostate gland & 61 & 15.8 & 349 & 90.4 \\
\hline Function of vas deferens & 168 & 43.5 & 336 & 87 \\
\hline Function of testis & 164 & 42.5 & 349 & 90.4 \\
\hline Name of male hormone & 124 & 32.1 & 359 & 93 \\
\hline Functions of male hormone & 156 & 40.4 & 349 & 90.4 \\
\hline Daily sperm count produced & 5 & 1.3 & 332 & 86 \\
\hline Seminal fluid characteristics & 134 & 34.7 & 326 & 84.5 \\
\hline Reason of located testis outside body & 119 & 30.8 & 324 & 83.9 \\
\hline Type of penis tissue & 100 & 25.9 & 334 & 86.5 \\
\hline Definition of erection process & 174 & 45.1 & 330 & 85.5 \\
\hline Time of erection occurrence & 141 & 36.5 & 340 & 88.1 \\
\hline Total male reproductive system $($ Scores $=13$ ) & & & & \\
\hline Poor & 315 & 81.6 & 0 & 0 \\
\hline Fair & 63 & 16.3 & 22 & 5.7 \\
\hline Good & 8 & 2.1 & 364 & 94.3 \\
\hline$\square$ ( SD) & \multicolumn{2}{|c|}{$4.179(2.541)$} & \multicolumn{2}{|c|}{$11.477(1.154)$} \\
\hline $\mathbf{t}$ & \multicolumn{4}{|c|}{$\mathbf{5 1 . 8 9 7}$} \\
\hline $\mathbf{P}$ & \multicolumn{4}{|c|}{$.000 * *$} \\
\hline Female reproductive system organs & 91 & 23.6 & 350 & 90.7 \\
\hline Function of ovary & 72 & 18.7 & 355 & 92 \\
\hline Function of Fallopian tube & 77 & 19.9 & 351 & 90.9 \\
\hline Name of female hormones & 67 & 17.4 & 339 & 87.8 \\
\hline Function of female hormones & 69 & 17.9 & 342 & 88.6 \\
\hline \multicolumn{5}{|l|}{ Total female reproductive system $($ Scores $=5$ ) } \\
\hline Poor & 336 & 87 & 2 & 0.5 \\
\hline Fair & 28 & 7.3 & 31 & 8 \\
\hline Good & 22 & 5.7 & 353 & 91.5 \\
\hline$\square$ ( SD) & \multicolumn{2}{|c|}{$0.974(1.246)$} & \multicolumn{2}{|c|}{$4.5(.665)$} \\
\hline $\mathbf{t}$ & \multicolumn{4}{|c|}{47.344} \\
\hline $\mathbf{P}$ & \multicolumn{4}{|c|}{$.000 * *$} \\
\hline
\end{tabular}

$\square$ ( SD): Mean (standard deviation)

t-value (Student's t-test)

P: Significance.

* Significant $(\mathrm{p}<0.05)$.

$* *$ Highly significant $(\mathrm{P}<0.01)$. 
APPLYING HEALTH EDUCATION PACKAGE ABOUT etc...

Table (45): Distribution of the studied students according to their correct knowledge about female maturation pre and post health education package application

\begin{tabular}{|c|c|c|c|c|}
\hline \multirow[t]{2}{*}{ Items } & \multicolumn{2}{|c|}{ Pre test } & \multicolumn{2}{|c|}{ Post test } \\
\hline & $\mathrm{N}=386$ & $\%$ & $\mathrm{~N}=386$ & $\%$ \\
\hline \multicolumn{5}{|l|}{ Female maturation } \\
\hline \multicolumn{5}{|l|}{ Signs of female maturation } \\
\hline Start of menstruation & 111 & 28.8 & 364 & 94.3 \\
\hline Concupiscence feeling & 113 & 29.3 & 358 & 92.7 \\
\hline Sexual organs development & 156 & 40.4 & 362 & 93.8 \\
\hline Hair growing on different body parts & 124 & 32.1 & 359 & 93 \\
\hline Hormonal changes & 112 & 29 & 364 & 94.3 \\
\hline Change tone of voice & 109 & 28.2 & 352 & 91.2 \\
\hline Wet dreams & 81 & 21 & 350 & 90.7 \\
\hline Age of starting female maturation & 94 & 24.4 & 346 & 89.6 \\
\hline Factors affect starting of female maturation & 50 & 13 & 352 & 91.2 \\
\hline Female identify sexual identity at childhood period & 34 & 8.8 & 352 & 91.2 \\
\hline Female identify sexual identity at adolescent period & 50 & 13 & 365 & 94.6 \\
\hline Female identify sexual identity at adulthood period & 40 & 10.4 & 350 & 90.7 \\
\hline Definition of menstruation & 101 & 26.2 & 356 & 92.2 \\
\hline Female maturation is related with menstruation & 107 & 27.7 & 354 & 91.7 \\
\hline Marriage depends on starting of menstruation & 120 & 31.1 & 362 & 93.8 \\
\hline Female genital circumcision definition & 132 & 34.2 & 360 & 93.3 \\
\hline Importance of female genital circumcision & 58 & 15 & 360 & 93.3 \\
\hline Complications of female genital circumcision & 33 & 8.5 & 354 & 91.7 \\
\hline \multicolumn{5}{|l|}{ Total female maturation $($ Scores $=18$ ) } \\
\hline Poor & 364 & 94.3 & 0 & 0 \\
\hline Fair & 22 & 5.7 & 1 & 0.3 \\
\hline Good & 0 & 0 & 385 & 99.7 \\
\hline$\square$ ( SD) & \multicolumn{2}{|c|}{$4.298(2.593)$} & \multicolumn{2}{|c|}{17.544 (1.099) } \\
\hline $\mathbf{t}$ & \multicolumn{4}{|c|}{93.235} \\
\hline $\mathbf{P}$ & \multicolumn{4}{|c|}{$.000 * *$} \\
\hline
\end{tabular}

$\square$ ( SD): Mean (standard deviation)

t-value (Student's t-test)

P: Significance.

* Significant $(\mathrm{p}<0.05)$.

** Highly significant $(\mathrm{P}<0.01)$. 
Mohamed Mustafa et. al.

Table (46): Distribution of the studied students according to their correct knowledge about male maturation pre and post health education package application

\begin{tabular}{|c|c|c|c|c|}
\hline \multirow[t]{2}{*}{ Items } & \multicolumn{2}{|c|}{ Pre test } & \multicolumn{2}{|c|}{ Post test } \\
\hline & $\mathrm{N}=386$ & $\%$ & $\mathrm{~N}=386$ & $\%$ \\
\hline \multicolumn{5}{|l|}{ Male maturation } \\
\hline \multicolumn{5}{|l|}{ Signs of male maturation } \\
\hline Concupiscence feeling & 172 & 44.6 & 349 & 90.4 \\
\hline Wet dreams & 174 & 45.1 & 335 & 86.8 \\
\hline Sexual organs development & 197 & 51 & 355 & 92 \\
\hline Hair growing on different body parts & 124 & 32.1 & 336 & 87 \\
\hline Hormonal changes & 152 & 39.4 & 363 & 94 \\
\hline Change tone of voice & 202 & 52.3 & 348 & 90.2 \\
\hline Age of starting male maturation & 158 & 40.9 & 364 & 94.3 \\
\hline Factors affect starting of male maturation & 65 & 16.8 & 352 & 91.2 \\
\hline Male identify sexual identity at childhood period & 66 & 17.1 & 339 & 87.8 \\
\hline Male identify sexual identity at adolescent period & 90 & 23.3 & 354 & 91.7 \\
\hline Male identify sexual identity at adulthood period & 63 & 16.3 & 360 & 93.3 \\
\hline Definition of ejaculation process & 142 & 36.8 & 363 & 94 \\
\hline Male maturation is related with ejaculation process & 156 & 40.4 & 365 & 94.6 \\
\hline Marriage depends on the occurrence of ejaculation & 131 & 33.9 & 350 & 90.7 \\
\hline Definition of men's purity & 109 & 28.2 & 360 & 93.3 \\
\hline Importance of men's purity & 42 & 10.9 & 347 & 89.9 \\
\hline \multicolumn{5}{|l|}{ Total male maturation $($ Scores $=16$ ) } \\
\hline Poor & 362 & 93.8 & 0 & 0 \\
\hline Fair & 24 & 6.2 & 5 & 1.3 \\
\hline Good & 0 & 0 & 381 & 98.7 \\
\hline$\square$ ( SD) & \multicolumn{2}{|c|}{$5.292(2.131)$} & \multicolumn{2}{|c|}{$14.611(1.258)$} \\
\hline $\mathbf{t}$ & \multicolumn{4}{|c|}{74.909} \\
\hline $\mathbf{P}$ & \multicolumn{4}{|c|}{$.000 * *$} \\
\hline
\end{tabular}

$\square$ ( SD): Mean (standard deviation)

t-value (Student's t-test)

P: Significance.

* Significant $(\mathrm{p}<0.05)$.

** Highly significant $(\mathrm{P}<0.01)$. 
APPLYING HEALTH EDUCATION PACKAGE ABOUT etc...

Table (47): Distribution of the studied students according to their correct knowledge about reproduction and sex pre and post health education package application

\begin{tabular}{|c|c|c|c|c|}
\hline \multirow[t]{2}{*}{ Items } & \multicolumn{2}{|c|}{ Pre test } & \multicolumn{2}{|c|}{ Post test } \\
\hline & $\mathrm{N}=386$ & $\%$ & $\mathrm{~N}=386$ & $\%$ \\
\hline \multicolumn{5}{|l|}{ Reproduction } \\
\hline Reproduction linked with maturation & 106 & 27.5 & 354 & 91.7 \\
\hline Appropriate time for marriage to male & 99 & 25.6 & 346 & 89.6 \\
\hline Appropriate time for marriage to female & 84 & 21.8 & 334 & 86.5 \\
\hline Definition of fertilization process & 110 & 28.5 & 338 & $\overline{87.6}$ \\
\hline Appropriate time for fertilization process & 35 & 9.1 & 341 & 88.3 \\
\hline Total Reproduction (Scores=5) & & & & \\
\hline Poor & 348 & 90.2 & 9 & 2.3 \\
\hline Fair & 29 & 7.5 & 29 & 7.5 \\
\hline Good & 9 & 2.3 & 348 & 90.2 \\
\hline$\square$ ( SD) & \multicolumn{2}{|c|}{$1.124(1.022)$} & \multicolumn{2}{|c|}{$4.438(.744)$} \\
\hline t & \multicolumn{4}{|c|}{48.173} \\
\hline $\mathbf{P}$ & \multicolumn{4}{|c|}{$.000 * *$} \\
\hline \multicolumn{5}{|l|}{ Sex } \\
\hline Concept of sex & 77 & 19.9 & 365 & 94.6 \\
\hline Suitable age for male to practice sex & 104 & 26.9 & 366 & 94.8 \\
\hline Suitable age for female to practice sex & 103 & 26.7 & 362 & 93.8 \\
\hline \multicolumn{5}{|l|}{ Youth facing intense of sexual desire by: } \\
\hline Wet dreams & 115 & 29.8 & 354 & 91.7 \\
\hline Practicing sports & 130 & 33.7 & 360 & 93.3 \\
\hline Masturbation & 104 & 26.9 & 250 & 64.8 \\
\hline Fasting and worship & 93 & 24.1 & 356 & 92.2 \\
\hline Watching exciting films & 105 & 27.2 & 251 & 65 \\
\hline Definition of wet dreams & 125 & 32.4 & 352 & 91.2 \\
\hline Wet dreams occur for both gender & 96 & 24.9 & 352 & 91.2 \\
\hline \multicolumn{5}{|l|}{ Total Sex $($ Scores=10) } \\
\hline Poor & 375 & 97.2 & 1 & 0.3 \\
\hline Fair & 10 & 2.6 & 53 & 13.7 \\
\hline Good & 1 & 0.3 & 332 & 86 \\
\hline$\overline{X(S D)}$ & \multicolumn{2}{|c|}{$2.725(1.451)$} & \multicolumn{2}{|c|}{$8.725(1.077)$} \\
\hline $\mathbf{t}$ & \multicolumn{4}{|c|}{66.882} \\
\hline$\overline{\mathbf{P}}$ & \multicolumn{4}{|c|}{$.000 * *$} \\
\hline
\end{tabular}

$\square$ ( SD): Mean (standard deviation)

t-value (Student's t-test)

P: Significance.

* Significant $(\mathrm{p}<0.05)$.

** Highly significant $(\mathrm{P}<0.01)$. 
Mohamed Mustafa et. al.

Table (6): Distribution of the studied students according to their correct knowledge about masturbation and sexual stimulants pre and post health education package application

\begin{tabular}{|c|c|c|c|c|}
\hline \multirow[t]{2}{*}{ Items } & \multicolumn{2}{|c|}{ Pre test } & \multicolumn{2}{|c|}{ Post test } \\
\hline & $\mathrm{N}=386$ & $\%$ & $\mathrm{~N}=386$ & $\%$ \\
\hline \multicolumn{5}{|l|}{ Masturbation } \\
\hline Definition of masturbation & 169 & 43.8 & 359 & 93 \\
\hline \multicolumn{5}{|l|}{ Effect of extensively practicing of masturbation } \\
\hline Sexual impotence & 116 & 30.1 & 363 & 94 \\
\hline Infertility & 134 & 34.7 & 367 & 95.1 \\
\hline Psychological disorders "depression" & 15 & 3.9 & 365 & 94.6 \\
\hline \multicolumn{5}{|l|}{ Total masturbation $($ Scores $=4)$} \\
\hline Poor & 361 & 93.5 & 9 & 2.3 \\
\hline Fair & 0 & 0 & 72 & 18.7 \\
\hline Good & 25 & 6.5 & 305 & 79.0 \\
\hline $\bar{X}(\mathrm{SD})$ & \multicolumn{2}{|c|}{$1.124(.886)$} & \multicolumn{2}{|c|}{$3.767(.475)$} \\
\hline $\mathbf{t}$ & \multicolumn{4}{|c|}{45.885} \\
\hline $\mathbf{P}$ & \multicolumn{4}{|c|}{$.000 * *$} \\
\hline \multicolumn{5}{|l|}{ Sexual stimulants } \\
\hline Definition of sexual stimulants & 101 & 26.2 & 355 & 92 \\
\hline \multicolumn{5}{|l|}{ Types of male sexual stimulants } \\
\hline Pills & 76 & 19.7 & 363 & 94 \\
\hline Injection & 12 & 3.1 & 353 & 91.5 \\
\hline Local & 41 & 10.6 & 365 & 94.6 \\
\hline Natural & 56 & 14.5 & 357 & 92.5 \\
\hline \multicolumn{5}{|l|}{ Types of female sexual stimulants } \\
\hline Pills & 61 & 15.8 & 352 & 91.2 \\
\hline Injection & 4 & 1.0 & 342 & 88.6 \\
\hline Local & 23 & 6 & 347 & 89.9 \\
\hline Natural & 40 & 10.4 & 332 & 86 \\
\hline Sexual stimulants uses & 77 & 19.9 & 357 & 92.5 \\
\hline Complications of sexual stimulants used by male & 71 & 18.4 & 348 & 90.2 \\
\hline Complications of sexual stimulants used by female & 35 & 9.1 & 352 & 91.2 \\
\hline \multicolumn{5}{|l|}{ Total sexual stimulants (Scores $=12$ ) } \\
\hline Poor & 373 & 96.6 & 0 & 0 \\
\hline Fair & 11 & 2.8 & 33 & 8.5 \\
\hline Good & 2 & 0.5 & 353 & 91.5 \\
\hline$\overline{X(S D)}$ & \multicolumn{2}{|c|}{$1.547(1.958)$} & \multicolumn{2}{|c|}{$10.940(1.003)$} \\
\hline $\mathbf{t}$ & \multicolumn{4}{|c|}{81.503} \\
\hline$\overline{\mathbf{P}}$ & \multicolumn{4}{|c|}{$.000 * *$} \\
\hline
\end{tabular}

X ( SD): Mean (standard deviation)

t-value (Student's t-test)

P: Significance.

* Significant $(\mathrm{p}<0.05)$.

** Highly significant $(\mathrm{P}<0.01)$. 
Table (49): Distribution of the studied students according to their correct knowledge about abnormal sexual behavior "Homosexuality" pre and post health education package application

\begin{tabular}{|c|c|c|c|c|}
\hline \multirow[t]{2}{*}{ Items } & \multicolumn{2}{|c|}{ Pre test } & \multicolumn{2}{|c|}{ Post test } \\
\hline & $\mathrm{N}=386$ & $\%$ & $\mathrm{~N}=386$ & $\%$ \\
\hline \multicolumn{5}{|l|}{ Abnormal sexual behavior "Homosexuality" } \\
\hline Definition of homosexuality & 57 & 14.8 & 298 & 77.2 \\
\hline \multicolumn{5}{|l|}{ Causes of homosexuality: } \\
\hline Personality defect and bad upbringing & 38 & 9.8 & 341 & 88.3 \\
\hline Social pressures & 98 & 25.4 & 334 & 86.5 \\
\hline Organic causes lead to chemical substances changes & 58 & 15 & 343 & 88.9 \\
\hline Genetic factors & 70 & 18.1 & 351 & 90.9 \\
\hline Acquired behavior resulted from childhood abuse & 66 & 17.1 & 349 & 90.4 \\
\hline Non-compliance with religious precepts & 120 & 31.1 & 353 & 91.5 \\
\hline \multicolumn{5}{|l|}{ Types of homosexuality } \\
\hline Gay & 203 & 52.6 & 349 & 90.4 \\
\hline Lesbian & 182 & 47.2 & 358 & 92.7 \\
\hline Anal or oral sex with female & 112 & 29 & 356 & 92.2 \\
\hline Zoophilia & 172 & 44.6 & 366 & 94.8 \\
\hline Pedophilia & 141 & 36.5 & 363 & 94 \\
\hline Hazards of homosexuality & 69 & 17.9 & 363 & 94 \\
\hline \multicolumn{5}{|l|}{ Total homosexuality:(Scores $=13$ ) } \\
\hline Poor & 361 & 93.5 & 0 & 0 \\
\hline Fair & 25 & 6.5 & 7 & 1.8 \\
\hline Good & 0 & 0 & 379 & 98.2 \\
\hline $\mathbf{X}(\mathrm{SD})$ & \multicolumn{2}{|c|}{$3.590(1.676)$} & \multicolumn{2}{|c|}{$\begin{array}{l}\mathbf{1 1 . 7 2 0} \\
(\mathbf{1 . 0 3 7})\end{array}$} \\
\hline $\mathbf{t}$ & \multicolumn{4}{|c|}{ 81.039 } \\
\hline $\mathbf{P}$ & \multicolumn{4}{|c|}{$.000 * *$} \\
\hline $\begin{array}{l}\text { Sources of information about homosexuality before } \\
\text { application of educational package }\end{array}$ & \multicolumn{2}{|c|}{$\mathrm{N}=386$} & \multicolumn{2}{|c|}{$\%$} \\
\hline Radio & \multicolumn{2}{|c|}{23} & \multicolumn{2}{|c|}{6.0} \\
\hline TV & \multicolumn{2}{|c|}{45} & \multicolumn{2}{|c|}{11.7} \\
\hline Journals & \multicolumn{2}{|c|}{55} & \multicolumn{2}{|c|}{14.2} \\
\hline Family and neighbors & \multicolumn{2}{|c|}{56} & \multicolumn{2}{|c|}{14.5} \\
\hline Friends & \multicolumn{2}{|c|}{53} & \multicolumn{2}{|c|}{13.7} \\
\hline Schools and universities & \multicolumn{2}{|c|}{43} & \multicolumn{2}{|c|}{11.1} \\
\hline Web & \multicolumn{2}{|c|}{42} & \multicolumn{2}{|c|}{10.9} \\
\hline
\end{tabular}

$\mathbf{X}$ ( SD): Mean (standard deviation)

t-value (Student's t-test)

P: Significance.

* Significant $(\mathrm{p}<0.05)$.

** Highly significant $(\mathrm{P}<0.01)$. 
Mohamed Mustafa et. al.

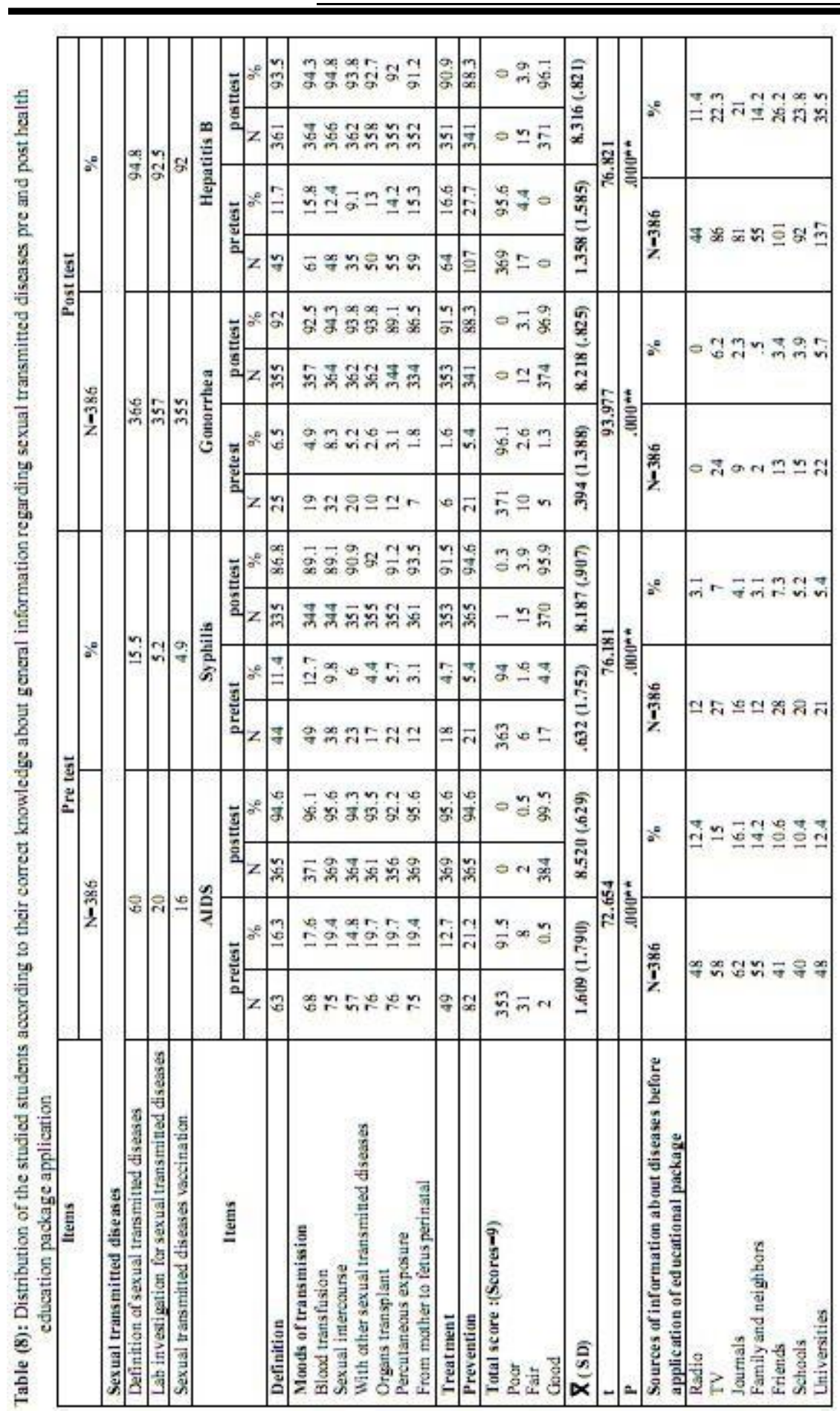


APPLYING HEALTH EDUCATION PACKAGE ABOUT etc...

Table (9): Distribution of the studied students according to their correct knowledge about reproductive health and family planning pre and post health education package application

\begin{tabular}{|c|c|c|c|c|}
\hline \multirow{2}{*}{ Items } & \multicolumn{2}{|c|}{ Pre test } & \multicolumn{2}{|c|}{ Post test } \\
\hline & $\mathrm{N}=386$ & $\%$ & $\mathrm{~N}=386$ & $\%$ \\
\hline \multicolumn{5}{|l|}{ Reproductive health } \\
\hline Definition of reproductive health & 51 & 13.2 & 336 & 87 \\
\hline Definition of family planning & 70 & 18.1 & 349 & 90.4 \\
\hline Importance of family planning & 83 & 21.5 & 339 & 87.8 \\
\hline Role of men in family planning & 46 & 11.9 & 333 & 86.3 \\
\hline Family planning methods for men & 87 & 22.5 & 336 & 87 \\
\hline Suitable number of children & 84 & 21.8 & 371 & 96.1 \\
\hline $\begin{array}{l}\text { There is an importance for legislate laws to promote } \\
\text { sexual and reproductive health }\end{array}$ & 114 & 29.5 & 350 & 90.7 \\
\hline Sex related laws in our community & 21 & 5.4 & 353 & 91.5 \\
\hline $\begin{array}{l}\text { Total reproductive health and family planning } \\
\text { (Scores=8) } \\
\text { Poor } \\
\text { Fair } \\
\text { Good }\end{array}$ & $\begin{array}{c}376 \\
10 \\
0\end{array}$ & $\begin{array}{c}97.4 \\
2.6 \\
0\end{array}$ & $\begin{array}{c}2 \\
80 \\
304\end{array}$ & $\begin{array}{c}.5 \\
20.7 \\
78.8\end{array}$ \\
\hline $\mathbf{X}(\mathbf{S D})$ & \multicolumn{2}{|c|}{$1.440(1.371)$} & \multicolumn{2}{|c|}{$7.168(.874)$} \\
\hline $\mathbf{t}$ & \multicolumn{4}{|c|}{65.850} \\
\hline $\mathbf{P}$ & \multicolumn{4}{|c|}{$.000 * *$} \\
\hline $\begin{array}{l}\text { Sources of information about sexual and } \\
\text { reproductive health before application of } \\
\text { educational package }\end{array}$ & \multicolumn{2}{|c|}{$\mathrm{N}=386$} & \multicolumn{2}{|c|}{$\%$} \\
\hline Radio & \multicolumn{2}{|c|}{65} & \multicolumn{2}{|c|}{16.8} \\
\hline TV & \multicolumn{2}{|c|}{69} & \multicolumn{2}{|c|}{17.9} \\
\hline Web & \multicolumn{2}{|c|}{59} & \multicolumn{2}{|c|}{15.3} \\
\hline Books and Journals & \multicolumn{2}{|c|}{64} & \multicolumn{2}{|c|}{16.6} \\
\hline Family and neighbors & \multicolumn{2}{|c|}{32} & \multicolumn{2}{|c|}{8.3} \\
\hline Friends & \multicolumn{2}{|c|}{57} & \multicolumn{2}{|c|}{14.8} \\
\hline Schools and Universities & \multicolumn{2}{|c|}{59} & \multicolumn{2}{|c|}{15.3} \\
\hline
\end{tabular}

X ( SD): Mean (standard deviation)

t-value (Student's t-test)

P: Significance.

* Significant $(\mathrm{p}<0.05)$.

** Highly significant $(\mathrm{P}<0.01)$. 
Mohamed Mustafa et. al.

Table (10): Distribution of the studied students according to their total correct knowledge about sexual and reproductive health pre and post health education package application

\begin{tabular}{|c|c|c|c|c|}
\hline \multirow{2}{*}{ Items } & \multicolumn{2}{|c|}{ Pre test } & \multicolumn{2}{|c|}{ Post test } \\
\hline & $\mathrm{N}=386$ & $\%$ & $\mathrm{~N}=386$ & $\%$ \\
\hline \multicolumn{5}{|l|}{ Sexual and reproductive health } \\
\hline $\begin{array}{l}\text { Total sexual and reproductive health } \\
\text { (Scores=143) } \\
\text { Poor } \\
\text { Fair } \\
\text { Good }\end{array}$ & $\begin{array}{c}385 \\
1 \\
0\end{array}$ & $\begin{array}{c}99.7 \\
0.3 \\
0\end{array}$ & $\begin{array}{c}0 \\
0 \\
386\end{array}$ & $\begin{array}{c}0 \\
0 \\
100\end{array}$ \\
\hline$\square$ ( SD) & \multicolumn{2}{|c|}{$\begin{array}{c}30.510 \\
(12.434)\end{array}$} & \multicolumn{2}{|c|}{$130.347(3.591)$} \\
\hline $\bar{t}$ & \multicolumn{4}{|c|}{151.995} \\
\hline $\mathbf{P}$ & \multicolumn{4}{|c|}{$.000 * *$} \\
\hline
\end{tabular}

$\square$ ( SD): Mean (standard deviation)

t-value (Student's t-test)

P:Significance

* Significant $(\mathrm{p}<0.05)$

** Highly significant $(\mathrm{P}<0.01)$.

Table (11): Distribution of the studied students according to their total attitude toward sexual and reproductive health pre and post health education package application

\begin{tabular}{|c|c|c|c|c|}
\hline \multirow{2}{*}{ Items } & Pre & Post & \multirow{2}{*}{$\mathbf{t}$} & \multirow{2}{*}{$\mathbf{P}$} \\
\hline & $\square$ ( SD) & $\square$ ( SD) & & \\
\hline Students attitude toward sex (44 marks) & $\begin{array}{l}32.705 \\
(3.781)\end{array}$ & $\begin{array}{l}41.979 \\
(1.704)\end{array}$ & 44.303 & $.000 * *$ \\
\hline $\begin{array}{l}\text { Students attitude toward abnormal sexual } \\
\text { behavior and sexual diseases ( } 60 \text { marks) }\end{array}$ & $\begin{array}{l}47.031 \\
(5.332)\end{array}$ & $\begin{array}{l}57.187 \\
(2.104)\end{array}$ & 35.397 & $.000 * *$ \\
\hline $\begin{array}{l}\text { Students attitude toward reproductive health( } 24 \\
\text { marks) }\end{array}$ & $\begin{array}{l}18.008 \\
(2.732)\end{array}$ & $\begin{array}{l}22.279 \\
(1.908)\end{array}$ & 25.225 & $.000 * *$ \\
\hline $\begin{array}{l}\text { Students attitude toward sexual education(64 } \\
\text { marks) }\end{array}$ & $\begin{array}{l}49.257 \\
(6.296)\end{array}$ & $\begin{array}{l}60.785 \\
(2.544)\end{array}$ & 34.190 & $.000 * *$ \\
\hline Total attitude (192 marks) & $\begin{array}{c}147.00 \\
(13.754)\end{array}$ & $\begin{array}{c}182.231 \\
(4.642)\end{array}$ & 49.150 & $.000 * *$ \\
\hline
\end{tabular}

X ( SD): Mean (standard deviation)

t-value (Student's t-test)

P: Significance.

* Significant $(\mathrm{p}<0.05)$.

** Highly significant $(\mathrm{P}<0.01)$. 
References:

1- Vibha, A. (2010). Knowledge and coping pattern among adolescents. Nightingale Nursing Times, 6:5760,64 .

2- Schwartz, S. (2010). Youth and postconflict reconstruction: agents of change. Washington, DC: USIP Press Books.

3- Central Agency for Public Mobilization And Statistics (2018). Egypt Census 2017. Retrieved from: http://www.capmas.gov.eg/Pages/Sta ticPages.aspx?page_id=7193.

4- Abdulrahim, S., El Shareef, M. \& Alameddine, M. (2010). The potential and challenges of an academic-community partnership in a low-trust urban context. J Urban Health, 87: 1017-20.

5- Makhoul, J., Alameddine, M. \& Afifi R.A. (2011). 'I felt that I was benefiting someone': youth as agents of change in a refugee community project. Health Educ Res, 27(5), 914926.

6- ICPD Programme of Action Summary. International Conference on Population and Development Cairo, Egypt: United Nations Department of Public Information; DPI/1618/POPe March 1995 Retrieved from: http://www.unfpa. org/public/cache/offonce/home/sitem ap/icpd/International-ConferenceonPopulation-and-Development/ICPDSummary.

7- Manjula, R., Kashinakunti, S.V., Geethalakshmi, R.G. \& Sangam DK. (2012). An educational intervention study on adolescent reproductive health among preuniversity girls in Davangere district, South India. Ann Trop Med Public Health, 5:185-9.
8- Lim, S. W., Chhabra, R., Rosen, A., Racine, A. D., \& Alderman, E. M. (2012). Adolescents' views on barriers to healthcare: A pilot study. Journal of Primary Care \& Community Health, 3(2), 99-103.

9- Klingberg- Allvin, M., Berggren, V., Binh, N.T., Bijay, B. \& Johansson A. (2012). Married men's first time experiences of early childbearing and their role in sexual and reproductive decision making: a qualitative study from rural Vietnam. Cult Health Sex, 14: 449-61.

10- Schaeffer, R.L., Mendenhall, W. \& Ott, L. (1990). Elementary Survey Sampling, Fourth Edition. Duxbury Press, Belmont, California.

11- El-Gilany, A., El-Wehady, A. \& ElWasify, M. (2012). Updating and validation of the socioeconomic status scale for health research in Egypt. Eastern Mediterranean Health Journal, 18(9), 962-968.

12- El Gelany, S. \& Moussa, o. (2012). Reproductive health awareness among educated young women in Egypt. International Journal of Gynecology and Obstetrics, 120 (2013), 23-26.

13-WHO, (2018). Repositioning family planning: Guidelines for advocacy action. USAID, World Health Organization. Retrieved from: http://www.who.int/reproductivehealth/publications/fpadvocacytool.pdf.

14- Schalet, A.T. (2011). Beyond abstinence and risk: A new paradigm for adolescent sexual health. Women's Health Issues, 21(3 Suppl):S5e7.

15- Kirby, D. (2007). Emerging answers: Research findings on programs to reduce teen pregnancy 
and sexually transmitted diseases.

Washington, D.C.: National

Campaign to Prevent Pregnancy Prevention.

16- Susheela, S., \& Darroch, E. (2012). Adding it up: Costs and benefits of contraceptive services estimates for 2012. Guttmacher Institute. Retrieved from:

http://www.guttmacher.org/pubs/AIU -2012-estimates

17- Ab Rahman, A., Ab Rahman, R., Ibrahim, M., Salleh, H., Ismail, S., Ali, S.,... Ahmad, A. (2011). Knowledge of sexual and reproductive health among adolescents attending school in Kelantan, Malaysia. Southeast Asian J Trop Med Public Health, 42(3) 717725.

18- Iqbal, S., Zakar, R., Zakar, M. \& Fischer, F. (2017). Perceptions of adolescents' sexual and reproductive health and rights: a cross sectional study in Lahore District, Pakistan. BMC International Health and Human Rights, 17:5.

19- Basaran, A. \& Naim, N. (2017). Information, Attitudes and Behaviours about Reproductive Health of a University's Students. International Journal of Caring Sciences, 10 (3):1545.

20- Meena, J.K., Verma, A., Kishore, J. \& Ingle, G. (2015). Sexual and Reproductive Health: Knowledge, Attitude, and Perceptions among Young Unmarried Male Residents of Delhi. International Journal of Reproductive Medicine, 2015 (Article ID 431460), 6 pages.

21- Sexual Health/Reproductive Health. (2005). Youth Reproductive Health Services Exhibitor Book. T.C. Ministry of Health, General Directorate of Maternal and Child
Health and Family Planning, Ankara, 127-132.

22- Koc, M. (2004). Puberty and its general aspects in terms of developmental psychology. J. Inst. Soc. Sci, 2, 231-256.

23- Kotwal, N., Gupta, N. \& Gupta, R., (2008). Awareness of Reproductive Health among Rural Adolescent Girls (A Comparative Study of School Going Girls and Dropout Girls of Jammu). Stud Home Comm Sci, 2(2): 149-154.

24- Harshana, A.K.S. \& Kapoor, S.K. (2018). A Study of Knowledge of Adolescent Boys of Urban Slum of Delhi regarding Development of Secondary Sexual Characters. Ind $J$ Youth Adol Health, 5(1): 1-29.

25- Dorle, A.S., Hiremath, L.D., Mannapur, B.S. \& Ghattargi, .CH. (2010). Awareness regarding puberty changes in secondary school children of Bagalkot, Karnataka - A crosssectional study. Journal of Clinical and diagnostic Research, 4(5): 30169.

26- DAS, B.M. \& RAY, S. (2007). Adolescent Male Reproductive Health: Awareness and Behavior among Peri-Urban and Rural Boys in West Bengal, India. International Journal of Men's Health, 6(2): 79-99.

27- Tamang, L., Raynes-Greenow, C., McGeechan, K. \& Black, K. (2017). Knowledge, experience, and utilisation of sexual and reproductive health services amongst Nepalese youth living in the Kathmandu Valley. Sexual \& Reproductive Healthcare, 11: 25-30.

28- Samkange-Zeeb, F., Mikolajczyk, R.T. \& Zeeb, H. (2013). Awareness and knowledge of sexually transmitted diseases among secondary school students in two 
German cities. J. Community Health, 38, 293-300.

29- Folasayo, A. T., Oluwasegun, A. J., Samsudin, S., Saudi, S. N., Osman, M., \& Hamat, R. A. (2017).

Assessing the Knowledge Level, Attitudes, Risky Behaviors and Preventive Practices on Sexually Transmitted Diseases among University Students as Future Healthcare Providers in the Central Zone of Malaysia: A Cross-Sectional Study. International journal of environmental research and public health, 14(2), 159.

30- Wong, L.P., Chin, C.K.L., Low,W.Y. \& Jaafar, N. (2008). HIV/AIDS-related knowledge among Malaysian young adults: Findings from a nationwide survey. J. Int. AIDS Soc, 10, 148.

31- Awang, H., Wong, L.P., Jani, R. \& Low, W.Y. (2013). Knowledge of sexually transmitted diseases and sexual behaviours among Malaysian male youths. J. Biosoc. Sci, 46, 214224.

32- Ministry of Health, Malaysia (MOH), (2014). Global AIDS

Response Progress Report 2014 Malaysia: Country Responses to HIV/AIDS. Retrieved from:http://www.aidsdatahub.org/site s/default/files/publication/Malaysia_ narrative_report_2014_\%282\%29.
33- Abdul-Zahra, N.H., Habib, O.S. \& Al-Mulla, A.Y. (2016). Knowledge of university students about family planning programme. 10.13140/RG.2.2.36340.96645.

34- Madeni, F., Horiuchi, S. \& Iida M. (2011). Evaluation of a reproductive health awareness program for adolescence in urban Tanzania-A quasi-experimental pre-test post-test research. Reproductive Health, 8:21.

35- Nugraheni, S.A., Martini, Kartasurya, M.I., Prihatini, I.J. \& Sulistyowati, E. (2018). Knowledge and attitudes about reproductive health and pregnancy preparedness: preliminary study of brides and grooms in Brebes district, Central Java, Indonesia. Int J Community Med Public Health, 5(6):2170-2176.

36- Manjula, R., Kashinakunti, S., Geethalakshmi, R.G. \& Sangam, D.K. (2012). An educational intervention study on adolescent reproductive health among preuniversity girls in Davangere district, South India. Ann Trop Med Public Health, 5(3), 185-189.

37- Mehrabi, S.H., Etemadi, A., Borjali, A. \& Sadipoor, E. (2016). The Effect of Puberty Education on Knowledge, Attitudes, and Function of Female Students. Patient Saf Qual Improv, 4(3): 405-409 